\title{
SMOKING AND BRAIN DERIVED NEUROTROPHIC FACTOR (BDNF) LEVEL IN SERUM
}

\author{
$\mathcal{B Y}$ \\ Laila M. El Zalabany, Doaa A. El Morsi, Sahar A.EL Dakroory, \\ Alyaa Aba El-Hassan and Amany Ragab Yousef* \\ Departments of Forensic Medicine and Clinical Toxicology and Clinical Pathology* \\ Mansoura Faculty of Medicine - Egypt
}

\begin{abstract}
Brain derived neurotrophic factor (BDNF) is a member of neurotrophins which are a family of proteins whose action influence neurons of the central nervous system. The aim of the present study is to compare the differences in serum BDNF level in smokers and nonsmokers to better clarify the relationship between smoking and BDNF. The BDNF is measured in 88 subjects chosen randomly (33 non smokers and 55 smokers). All subjects are free from any chronic physical disease, allergy, psychiatric disorders and regular medications. A self - made questionnaire is given to each subject stating the age, amount of cigarette use (no. of cigarette / day), age of the first use and duration of use. Body mass index are calculated. In addition, Fagerstrom test for nicotine dependence (FTND) and smoking index are calculated. The results reveal no significant difference between BDNF level in smokers and non smokers. It is concluded that although BDNF level in the present study does not show any significant difference between smokers and non-smokers, this relationship needs further researches to be established and future studies will need to recruit more subjects in order to increase the statistical power of the research.
\end{abstract}

Key words: Neurotrophines, BDNF, Smoking, Nicotine, Drug of abuse.

\section{INTRODUCTION}

Tobacco use is associated with five million deaths per year worldwide and is regarded as one of the leading causes of early death (Hatsukami et al., 2008). Nicotine is the primary addictive component of tobacco and most people who smoke regularly develop nicotine dependence. Although nicotine is not generally classified as one of the strong addictive drugs such as cocaine and heroin, cigarette smoking is often a very difficult habit to break (Kim et al., 2007).

Neurotrophins are a family of proteins whose action influence neurons of the central nervous system (Huang and Reichardt, 2001). Neurotrophins family in mammals consists of four members : nerve growth factor (NGF), BDNF, neurotrophin 3 (NT-3) and neurotrophin 4/5 (NT-4/5) (Bertaux et al., 2004). 
It was found that under normal circumstances, the biological response of neurotrophins through their receptors include proliferation and survival; axonal and dendritic growth, synapse formation, function and plasticity. Under pathological circumstances, the level of proneurotrophins increase thus resulting in increased neuronal, dendritic and synaptic apoptotic deterioration (Buckley et al., 2007).

Brain derived neurotrophic factor is a member of neurotrophines which is one of the most abundant neurotrophic factors in the brain. It is widely expressed in the hippocampus, septum, cortex, and in adrenergic brain stem nuclei (Chao et al., 2006). The alteration of BDNF has been found to modulate several addictive behaviors associated with the actions of certain drugs of abuse (Bhang et al., 2010).

Recently BDNF which has been intensely investigated in the context of depression and anxiety disorders became also a target to examine the biological underpinnings of nicotine dependence (Groves, 2007).

A study done on humans by Kim et al. (2007) found that measured serum levels of BDNF in smokers and non-smokers support the notion of a possible relation between BDNF and smoking. They found that the smoking group had significantly lower BDNF baseline with a significantly higher rise of BDNF serum levels after two months of smoking cessation. However, there were few investigations concerning the changes in BDNF levels during chronic exposure to or withdrawal from cigarette smoking in clinical subjects with nicotine dependence.

In animal studies, regional brain BDNF expression was altered by exposure to or withdrawal from nicotine. Several animal studies suggest that BDNF plays an important role in drug addiction. Among these, the study done by Horger et al. (1999) which reported that the infusion of BDNF into the nucleus accumbens lead to enhanced cocaine-conditioning. These findings suggest that BDNF acts upon the reward system of the brain, which plays a key role in drug addiction (Goldstein and Volkow, 2002).

In the present study, the differences in BDNF level in smokers and nonsmokers is compared to better clarify the relationship between smoking and BDNF.

\section{SUBJECTS \& METHODS}

Subjects: In the present study 88 subjects were chosen randomly (33 non smokers and 55 smokers). All subjects were free from any chronic physical disease, allergy, psychiatric disorders and regular medications. In addition, a self - made question- 
naire was given to each subject stating the age, amount of cigarette use (no. of cigarettes / day), age of first use and duration of use. Also the height and weight were measured to calculate body mass index (BMI) (Weight / Height ${ }^{2}$ ). In addition, Fagerstrom test for nicotine dependence (FTND) (Heatherton, 1991) and smoking index (No. of cigarettes / day X No. of years of smoking) (Matsubara et al., 2002) were calculated.

\section{Fagerstrom Nicotine Dependence} Scale (FTND):

1. How soon after you wake up do you smoke your first cigarette?
a. Within 5 minutes ( 3 points)
b. Within 6-30 minutes (2 points)
c. Within $31-60$ minutes (1 point)
d. After 60 minutes ( 0 points)

2. Do you find it difficult to refrain from smoking in places where it is forbidden (e.g. at the library, in cinema, etc)?
a. Yes (1 point)
b. No (0 points)

3. Which cigarette would you hate most to give up?

a. The first one in the morning (1 point).

b. Any other (0 points).

4. How many cigarettes per day do you smoke?
a. 10 or less ( 0 points)
b. 11-20 (1 point)
c. $21-30$ (2 points)
d. 31 or more (3 points)

5. Do you smoke more during the first hours after waking than during the rest of the day?
a. Yes (1 point)
b. No (0 points)

6. Do you smoke even when you are ill enough to be in bed most of the day?
a. Yes (1 point)
b. No (0 points)

A score of 5 or more indicates a significant dependence, while a score of 4 or less shows a low to moderate dependence.

Sampling : Three $\mathrm{ml}$ blood samples were collected from each subject after taking informed consent to measure BDNF concentration. Samples are allowed to clot for 30 minutes then centrifuged for 15 minutes at $1000 \mathrm{Xg}$ and stored at $-40^{\circ} \mathrm{C}$ till the analysis.

Sample preparation : Polypropylene tubes were used to dilute the serum samples 20 folds by the use of the calibrator diluents just prior to the assay. $10 \mu \mathrm{l}$ serum was added to $190 \mu$ calibrator diluents RD6P (Barakat-Walter, 1996).

Principle of the assay: This assay emp- 
lys the quantitative sandwich enzyme immunoassay technique by the use of "quantikine" R \& D systems, Inc. Minneapolis, USA. A monoclonal antibody specific for BDNF has been pre - coated onto a microplate standard, samples are pipetted into the wells and any BDNF present is bound by the immobilized antibody. Following a wash to remove any unbound antibody enzyme reagent, a substrate solution is added to the wells and color develops in proportion to the amount of BDNF bound in the initial step. The color development is stopped and the intensity of the color is measured by the Enzyme Linked Immunosorbent Assay (ELISA) reader set at 450 $\mathrm{nm}$ with wavelength correction set at 570 nm (Kokaia et al., 1996).

Statistical analysis: The statistical analysis of data done by using Excel program and SPSS program statistical package for social science version 10 . To test the normality of data distribution, K-S (Kolmogorov-Smirnov) test was done only significant data revealed to be nonparametric.

N. B. : all tested data revealed to be parametric.

The description of the data done in the form of mean \pm SD for quantitative data; frequency and proportion for qualitative data. The analysis of the data was done to test statistical significant difference between groups. One way ANOVA test to compare more than two groups. For quantitative data student t-test was used to compare between two groups. Chi Square test $\left(\chi^{2}\right)$ was used for qualitative data. Correlation coefficiency was done to detect association between variables. $\mathrm{p}$ is significant $<0.05$.

\section{RESULTS}

Table (1) shows the baseline characteristics of smokers $(\mathrm{n}=55)$ and non smokers $(\mathrm{n}=33)$. Significant difference between the age of smokers and non - smokers; the mean \pm SD of age in smokers and non smokers is $(33.672 \pm 7.710 \& 29.303 \pm 3.432$ years) respectively. Also there is significant difference of BMI between smokers and non - smokers. The mean \pm SD of BMI in smokers and non smokers is $(26.768 \pm$ $3.583 \& 25.030 \pm 4.107 \mathrm{~kg} / \mathrm{m}^{2}$ ) respectively. The mean \pm SD of BDNF level in smokers and non smokers is (20402.04 \pm $10494.057 \& 18390.67 \pm 9331.521 \mathrm{pg} / \mathrm{ml}$ ) respectively but non significant. As regards the smokers; the mean \pm SD of age of first use of cigarette is $20.4545 \pm 5.5103$ years and the mean \pm SD of duration of use is $21.4727 \pm 13.5767$ years and the mean \pm SD of the amount of use is 13.2545 \pm 6.6031 cigarette / day. By studying the FTND and smoking index they are (4.272 $\pm 2.272 \& 15.2755 \pm 12.971)$ respectively.

Figure (1): Demonstrates positive correlation between BDNF and age of the first 
use. The youngest the age of the first use; the highest the BDNF level in serum.

\section{DISCUSSION}

Growth factors are required for the normal development and functioning of the nervous system. One group of growth factors includes the neurotrophins, a family of secretory proteins, consisting of nerve growth factor, brain-derived neurotrophic factor (BDNF), neurotrophin-3, and neurotrophin $-4 / 5$. Of the neurotrophins, BDNF plays a significant role in the promotion of normal nervous system development, and in regulating cell survival and apoptosis (Balkowiec and Katz, 1998).

In the present study, the differences in serum BDNF level in smokers and nonsmokers to better clarify the relationship between smoking and BDNF level.

Furthermore, no correlations were found between the plasma BDNF levels and the demographic or smoking-related clinical variables in the smoker group except for the positive correlation found between the age of the first use and the BDNF level. There were significant difference between smokers and non - smokers as regard the age and BMI. However the BDNF level was found to be higher in smokers than in non - smokers but this difference was statistically insignificant. To our knowledge, there are few studies which investigate the changes in the plasma BDNF levels of clinical subjects with nicotine dependence.

The results of Kenny et al. (2000) showed that acute administration of nicotine decreases BDNF level whereas chronic nicotine increases BDNF levels in the hippocampus. On the other hand, Zhang et al. (2010) stated that BDNF levels were significantly higher in smokers than in non - smokers $(p<0.05)$.

A study done by Thomas et al. (2008) found that the kinetics of BDNF expression by nicotine exposure in animal studies remain controversial because it has been suggested that acute exposure to nicotine typically decreases BDNF levels in contradiction to a previous study that demonstrated an increase in BDNF expression by long-term nicotine exposure (Kenny et al., 2000). Considering the function of BDNF, this finding might be indicative of a breakdown in an endogenous neuroprotective mechanism or of continuous functional down-regulation of BDNF by chronic smoking.

However, the present results are inconsistent with the findings of a previous proteomic analysis in the rat brain in which BDNF expression was decreased at both the protein and mRNA levels by repeated exposure to nicotine (Yeom et al., 2005). 
On contrary to the present study Bhang et al. (2010) reported that baseline serum BDNF levels were significantly lower in smokers compared to non - smokers $(\mathrm{F}=4.410, \mathrm{p}=0.002)$. The same findings were noticed in Kim et al. (2007) who stated that the baseline serum BDNF levels in smokers were significantly lower than those in non - smokers ( $F=4.626, p=0.038)$.

A limitation to this study is that the BDNF levels were measured in the serum, and although it has been reported that BDNF may cross the blood-brain barrier (Pan et al., 1998), yet this hypothesis has not been confirmed. Although certain amounts of BDNF are stored in platelets and subsequently released, it is believed that a major portion of human plasma BDNF may originate from the brain (Fujimura et al., 2002).

It could be concluded that the relationship between BDNF level and smoking needs further researches to be established and one limitation of the present study is that the sample size was relatively small. Future studies will need to recruit more subjects in order to increase the statistical power of the research. 
Table (1): Baseline characteristics of smokers $(n=55) \&$ non smokers $(n=33)$.

\begin{tabular}{|l|c|c|c|c|c|c|}
\hline \multicolumn{1}{|c|}{ Characteristics } & \multicolumn{1}{|c|}{$\begin{array}{c}\text { Smokers } \\
\text { (N= 55) } \\
\text { Mean } \pm \text { SD }\end{array}$} & $\begin{array}{c}\text { Non Smokers } \\
\text { Mean } \pm \text { SD } \\
\text { Me }\end{array}$ & Range & t & p \\
\hline Demographics & $33.672 \pm 7.710$ & $29.303 \pm 3.432$ & & 3.073 & $0.003^{* *}$ \\
\hline Age (years) & $26.768 \pm 3.583$ & $25.030 \pm 4.107$ & & 2.085 & $0.040 * *$ \\
\hline Body Mass Index (Kg / m $\left.{ }^{2}\right)$ & $20402.04 \pm 10494.057$ & $18390.67 \pm 9331.521$ & & 0.906 & 0.367 \\
\hline BDNF level (pg / ml) & $20.4545 \pm 5.5103$ & & $9-35$ & & \\
\hline Smoking Related dat a & $21.4727 \pm 13.5767$ & & $3-30$ & & \\
\hline Age of first use (years) & $13.2545 \pm 6.6031$ & & $5-60$ & & \\
\hline Duration of use (years) & $4.272 \pm 2.272$ & & & \\
\hline Amount of use (Cigarettes / d) & $15.2755 \pm 12.971$ & & & \\
\hline Scores of FTND & & & & \\
\hline Smoking index & & & & \\
\hline
\end{tabular}

FTND $=$ Fagerstrom Test for Nicotine Dependence. Significant level at $\mathrm{p}<0.05$. 


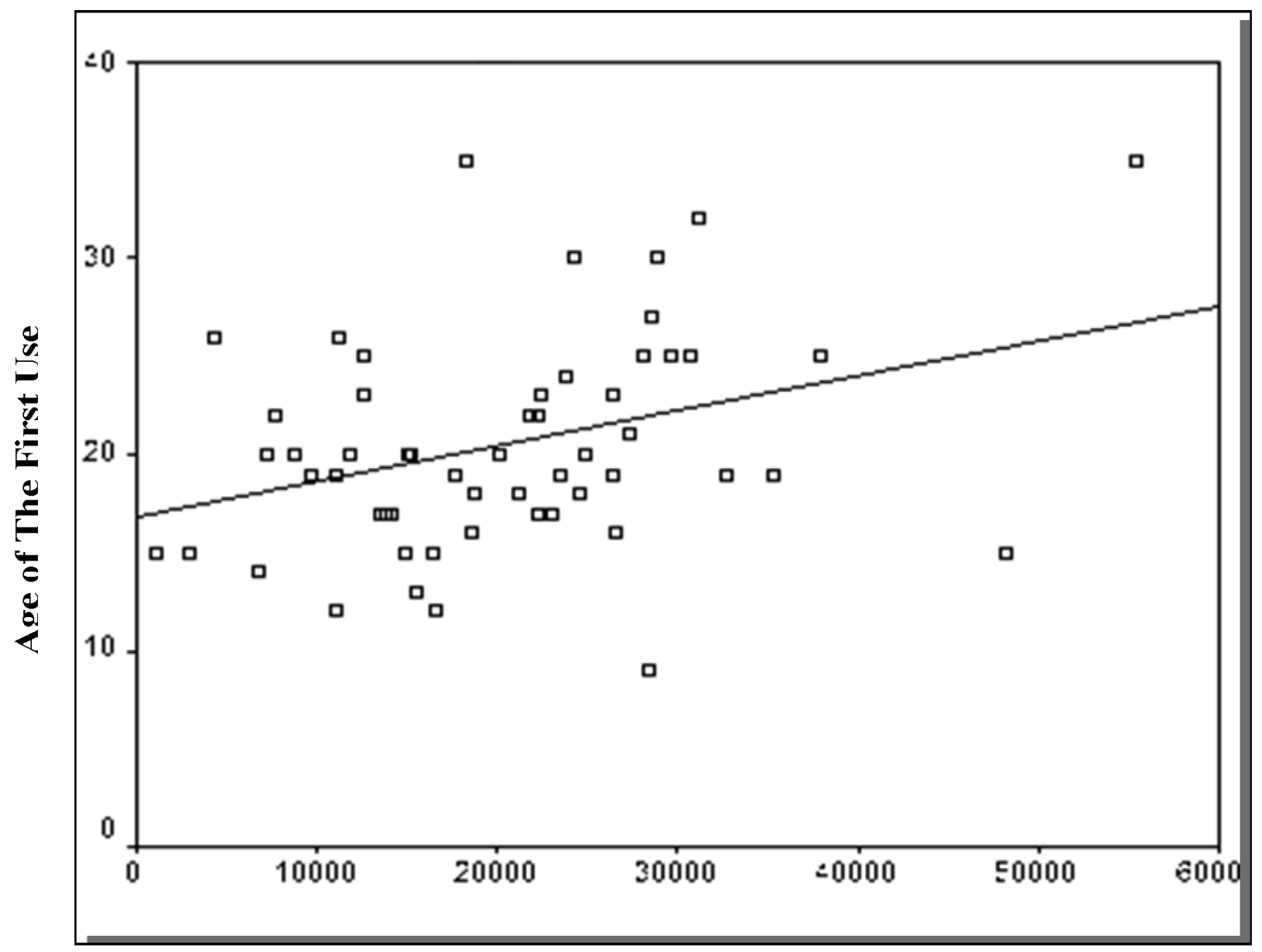

BDNF Conc. (pg /ml)

Figure (1): Correlation between BDNF concentration in blood and age of the first use of cigarette. 


\section{REFERENCES}

Balkowiec, A. and Katz, D. M. (1998) : "Brain-derived neurotrophic factor is required for normal development of the central respiratory rhythm in mice". J. Physiol., 510: 527-533.

Barakat-Walter, I. (1996) : "Brainderived neurotrophic factor-like immunoreactivity is localized mainly in small sensory neurons of rat dorsal root ganglia". J. Neuro. Sci. Methods, 68(2): 281-288.

Bertaux, O.; Toselli-Mollereau, E.; Auffray, C.; et al. (2004) : "Alternative usage of five exons in the chicken nerve growth factor gene: Refined characterization of a weakly expressed gene". Gene, 334:83-97.

Bhang, S. Y.; Choi, S. W. and Ahn, J. H. (2010) : "Changes in plasma brain derived neurotrophic factor levels in smokers after smoking cessation". Neuroscience Letters, 468:7-11.

Buckley, P. F.; Mahadik, S.; Pillai, A.; et al. (2007) : "Neurotrophins and schizophrenia". Schizophrenia Research, 94:1-11.

Chao, M. V.; Rajagopal, R. and Lee, F. S. (2006) : "Neurotrophin signaling in health and disease." Clin. Sci., 110:167-173.

Fujimura, H.; Altar, C. A.; Chen, R.; Nakamura, T.; Nakahashi, T.; Kambaya- shi, J.; Sun, B. and Tabdon, N. N. (2002) : "Brain-derived neurotrophic factor is stored in human platelets and released by agonist stimulation". Thromb. Haemost., 87: 728-734.

Goldstein, R. Z. and Volkow, N. D. (2002) : "Drug addiction and its underlying neurobiological basis : neuroimaging evidence for the involvement of the frontal cortex". Am. J. Psychiatry, 159:16421652.

Groves, J. O. (2007) : "Is it time to reassess the BDNF hypothesis of depression"? Mol. Psychiatry, 12: 1079-1088.

Hatsukami, D. K.; Stead, L. F. and Gupta, P. C. (2008) : "Tobacco addiction". Lancet, 371:2027-2038.

Heatherton, T. F. (1991) : "The Fagerström test for nicotine dependence: a revision of the Fagerström tolerance questionnaire". British Journal of Addiction, 86:1119-1127.

Horger, B. A.; Iyasere, C. A.; Berhow, M. T.; Messer, C. J.; Nestler, E. J. and Taylor, J. R. (1999) : "Enhancement of locomotor activity and conditioned reward to cocaine by brain-derived neurotrophic factor". J. Neurosci., 19: 4110-4122.

Huang, E. J. and Reichardt, L. F. (2001) : "Neurotrophins: Roles in neuronal 
development and function". Annu. Rev. Neurosci., 2:677-786.

Kenny, P. J.; File, S. E. and Rattray, M. (2000) : "Acute nicotine decreases, and chronic nicotine increases the expression of brain-derived neurotrophic factor mRNA in rat hippocampus". Brain Res. Mol. Brain Res., 85: 234-238.

Kim, T. S.; Kim, D. J.; Lee, H.; et al. (2007) : "Increased plasma brain derived neurotrophic factor levels in chronic smokers following unaided smoking cessation". Neuroscience Letters, 423 : 5357.

Kokaia, Z.; Nawa, H.; Uchino, H.; Elmer, E. and Kokaia, M. (1996) : "Regional brain-derived neurotrophic factor mRNA and protein levels following transient forebrain ischemia in the rat". Brain Res. Mol. Brain Res., 38(1): 139 - 144.

Matsubara, F.; Kida, M.; Tamakoshi, A.; Wakai, K.; Kawamura, T. and Ohno, Y. (2002) : "Maternal active and passive smoking and fetal growth: a prospective study in Nagoya, Japan". J. Epidemiol., 10: $335-343$.

Pan, W.; Banks, W. A.; Fasold, M. B.; Bluth, J. and Kastin, A. J. (1998) : "Transport of brain-derived neurotrophic factor across the blood - brain barrier." Neuropsychopharmacology, 37: 1553-1561.

Thomas, M. J.; Kalivas, P. W. and Shaham, Y. (2008): "Neuroplasticity in the mesolimbic dopamine system and cocaine addiction." Br. J. Pharmacol., 154 : 327 342.

Yeom, M.; Shim, I.; Lee, H. J. and Hahm, D . H. (2005) : "Proteomic analysis of nicotine associated protein expression in the striatum of repeated nicotinetreated rats". Biochem. Biophys. Res. Commun., 326: 321-328.

Zhang, X. Y.; Xiu, M. H.; Chen, D. C.; De Yang, F.; Wu, G. Y.; Lu, L.; Kosten, T. A. and Kosten, T. R. (2010) : "Nicotine dependence and serum BDNF levels in male patients with schizophrenia". Psychopharmacology (Berl). 


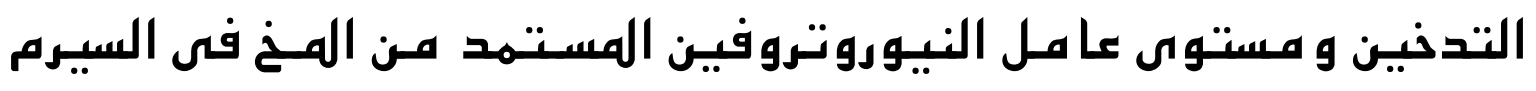 المشتركون فى البحث}

د. دعاء عبدالوهاب أحهد الهرسى

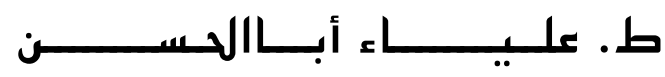

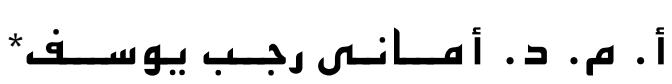

من قسـمى الطب الشرعى والسموم الإكلينيكية والباثولوجيا الإكلينيكية* كلية الطب - جامعة المنصورة

$$
\text { من قسمىى الطب }
$$$$
\text { كلية الطب - جام }
$$

أ. د. ليلـى مــهـــــد الزلبـــانـى

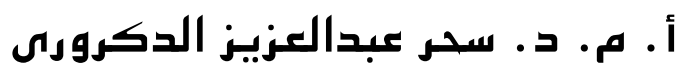

يععد النيوروتـروفين من عـائلة النيـوروتروفـينـات وهى مجمسوعة من البروتينات التى تؤثر على حيوية ونمو وشكل الخلايـا العصبيـة للجهاز العصبى المركزى، ويسهدف هذا البحث إلى المقارنة بين مستـوى النيوروتروفينات فى السيرم فى المدخنين مقارنة بغير المدخنين، وقد تمت الدراسة على 11 شخص (س من غير المدخنين و 00 من المدخنين) تم إختيارهم عشـوائياً وجميع الأشخاص محل الدراسة لايعانسون من أمراض عضوية مزمـنة أو حساسية أو أمراض نفسية ولايتـناولون أى عقاقير، وتم أخذ ب مـللى دم من كل شخص بعـد أخذ موافقة كتابيـة منهم لقياس مستوى مئى عامل النيوروتروفين المستمد من المخ بها، وقد تم ملىىء إستبيان عن العمر وعدد السجائر التى يتم تدخينها فى اليوم والعمر الذى تم تدخين أول سيـجارة به وعدد سنوات التدخين وكذلك تم قياس الطول والوزن لحسـاب معامل كتلة الجسم وحساب فجرستورم للتدخين ومعامل التدخين ، وقد أثبتت الدراسة وجود إرتفاع فى متسوسط مستوى عامل النيسوروتروفين المستمد من المخ فى المدخنين وغير المدخنين ولكنه ليس له دلالة إحصائية، ويمكن أن نستخلص أنه بـالرغم من أن مسـتوى النـيوروتروفين المستمـد من المـخ فى هذه الدراسة لم يظهر أى إختلاف ذو دلالة إحصائيسة بين المدخنين وغـير المدخنين فهذه العلاقـة تحــاج العـديـد من الأبـحـاث لإثباتها ، كمـا يجب أيضاً زيـادة حجم العيــة محل الدراسـة لزيادة القوة الإحصائية للبحث. 